\title{
List of tables, boxes and appendices
}

\section{Tables}

1.1 Asymmetry of population of fully fledged constituent units in federal systems

2.1 Dates of declarations of sovereignty

4.1 Ethnic composition of the republics, 1989

4.2 Ethnic composition of the autonomous areas, 1989

4.3 Ethnic composition of government elite in Bashkortostan, 1990-97

4.4 Ethnic representation of parliamentary elite, 1980-95

5.1 Share of the income of federal and territorial (subnational) budgets in total state revenue, 1992-2001

5.2 Top ten and bottom ten regions of Russia according to volume of gross regional product (GRP) in 1998 and industrial production (IP) in 1999

5.3 Ten largest regions according to their share of total volume of foreign investment in 1995 and 1999 (\%)

5.4 Concentration of tax contributions to the federal budget, 1996-98

5.5 Regional variations in per capita income and expenditure, 1999

5.6 Measuring poverty in Russia's regions, 1996-97 80

$5.7 \%$ of local taxes maintained by subjects of the Federation, 1996

5.8 Federal transfers as \% of total income in twelve selected regions, 1994-96

5.9 Typology of regions of Russia according to the share of federal budget transfers as a \% of total budget income, 1999

5.10 Variations in the financial status of subjects of the Russian Federation with different constitutional status, 1996 
5.11 The portion of taxes credited to the budgets of 'privileged republics' in 1992-98 as a \% of total taxes collected in each republic's territory

5.12 Economic status of the seven federal districts 89

6.1 Party representation in regional assemblies 98

6.2 Number of seats won by candidates of national parties and number of assemblies in which parties have seats, January 1998

6.3 Comparisons of registered candidates with winners, 1995-97

6.4 Variations in the level of governors' support of parties, 1999

6.5 Regional distribution of parties in the December 1999 Duma elections

7.1 Turovskii's classification of regional legislatures, 1997

9.1 Comparative prima facie evidence of electoral competitiveness and non-competitiveness in elections for the chief executive in the eighty-nine subjects of the Russian Federation

\section{Boxes}

1.1 Federal structure of the Russian Federation 8

4.1 The inter-regional associations $\quad 64$

6.1 Political affiliation of Russian governors 102

7.1 Variations in the powers of legislative and executive bodies of power as stipulated in regional and republican charters and constitutions

8.1 The seven federal districts

\section{Appendices}

3.1 Article 71 of the December 1993 Russian Constitution

3.2 Article 72 of the December 1993 Russian Constitution

6.1 Party membership of regional assemblies, January 1998 